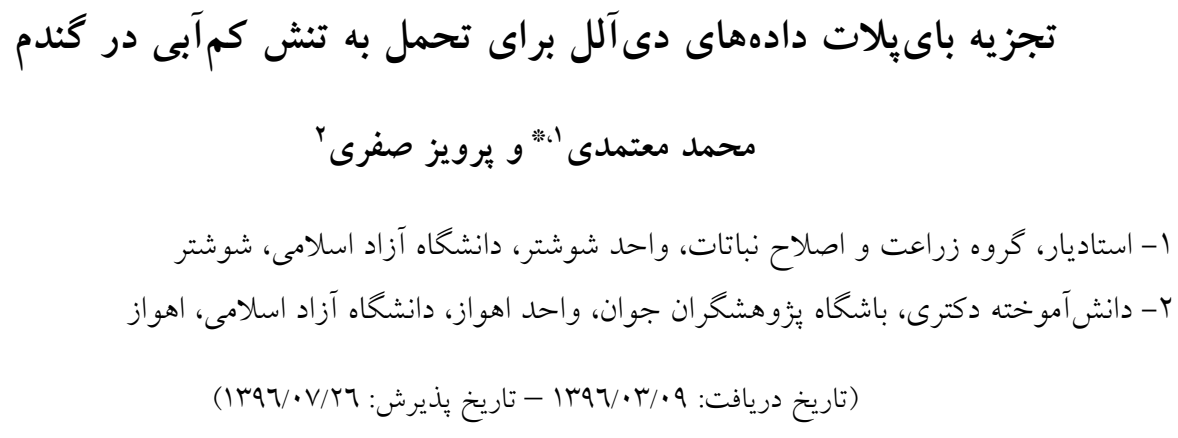

تنش كمآبى يكى از مهمتر ين عوامل كاهش توليد محصول كندم است و شناخت ساختار زنتيكى و نوع عمل زنهاى كنترل كننده

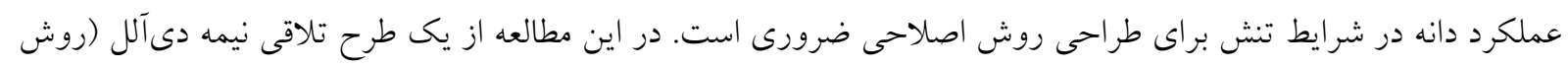

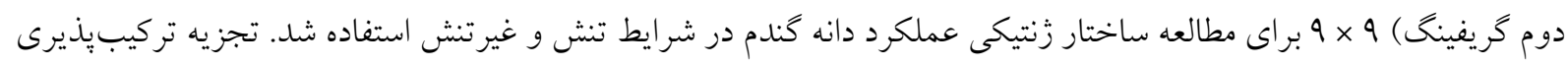

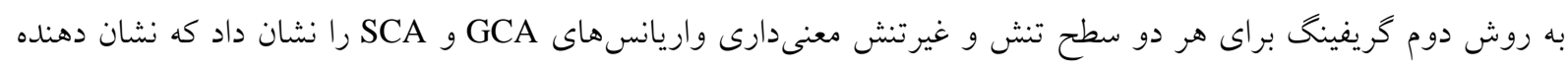

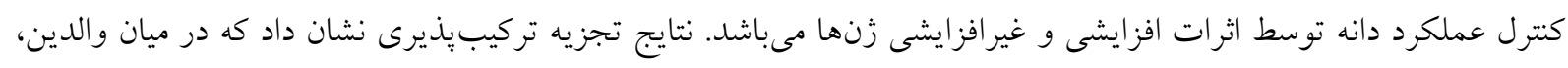

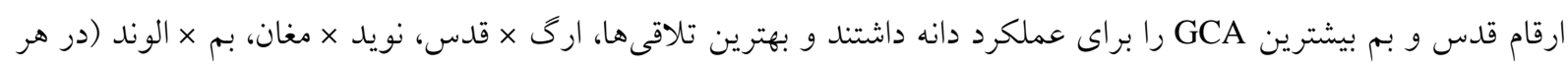

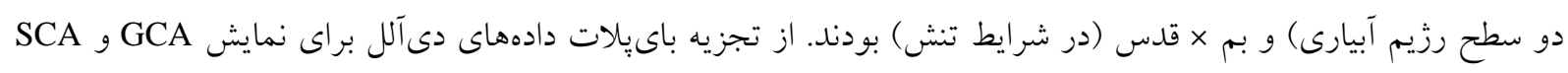

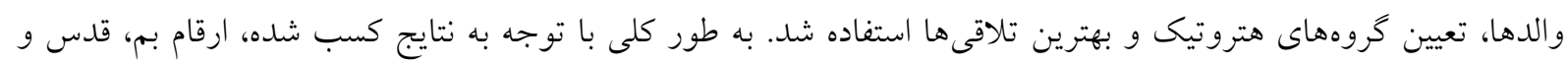

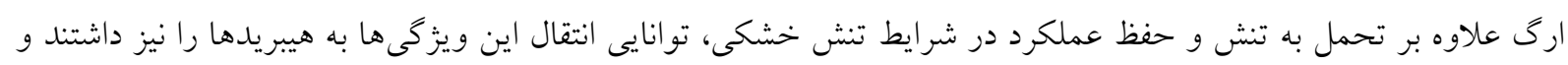

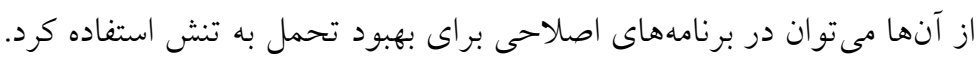

وازگگان كليدى: تركيبزيذيرى عمومى، تركيبذيذيرى خصوصى، دىآلل، تنش كمآبى، كندم 


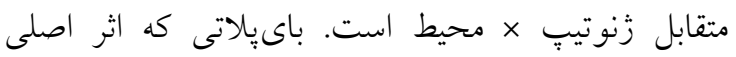

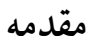
زنوتيب (G) و اثر متقابل GE را در مورد مجموعه دادهها نشان مىدهد، باىيلات GGE ناميده مىشود. يان و هانت - نشان دادند كه تجزيه متداول داده (Yan and Hunt, 2002) هاى دىآلل به تقسيم تغييرات كل تلاقىها به GCA هر والد و SCA هر تلاقى محدود مىشود. اثرهاى SCA فقط باقىماندههاى غير قابل توضيح توسط اثرهاى GCA محسوب مىشوند. اين اثرها مختص تلاقىها هستند و اطلاعات زيادى در مورد والدين ارايه نمىدهند. رويكرد باىيلات براى تجزيه دادههاى دى آلل امكان نمايش اطلاعات در مورد اثر GCA هر والد، اثر SCA هر و الد (نه هر تلاقى)، شناسايى بهترين تلاقىها، شناسايى بهترين محكها، شناسايى گروههاى هتروتيك و درى ساختار زنتيكى والدين به صورت گر افيكى را فراهم مى كند ( Yan and Hunt, 2002; Yan and Kang, 2003 هاشمىنسب (Farshadfar and Hasheminasab, 2012) تركيب يذيرى و ساختار زنتيكى شاخصهاى فيزيولوزيكى تحمل به تنش خشكى را در تلاقىهاى دىآلل كندم با لتيا

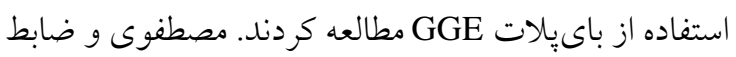
براى شناخت ساختار (Mostafavi and Zabet, 2013) زنتيكى عملكرد و تعيين بهترين زنوتيبٍهاى داراى تركيبيذيرى عمومى و خصوصى از باىيلات دادههاى تلاقى دى آلل كندم استفاده كردند و ضمن تعيين گرووهاى هتروتيك، مطابقت خوبى بين نتايج روش متداول گريفينگ و نتايج گرافيكى روش باىيلات GGE كزارش كردند.

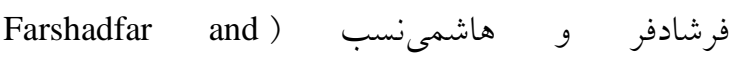
(Hasheminasab, 2013 تلاقى هاى هتروتيك و برآورد اجزاى افزايشى و غالبيت تنوع براى تحمل به تنش خشكى در كندم استفاده كردند. هدف از انجام اين مطالعه برآورد اثرات GCA و الدها و اثرات SCA تلاقى ها و شناخت GCA و SCA والدها، تعيين گروههاى هتروتيك و بهترين تلاقى ها در سطح تيمارهاى آبيارى و تنش توسط روش باىيلات براى عملكرد دانه بود.

كَندم مهمترين كياه زراعى در ايران است، جايى كه خشكى معلى اصلىترين تنش غير زيستى محسوب مى شود و عملكرد و كيفيت دانه را در طى دوره بر شدن دانه به شدت تحت تاثير قرار مىدهد و موجب كاهش عملكرد و كيفيت دانه مىشود (Nezhadahmadi et al., 2013). انتخاب روش هاى كزينش و بهنزادى براى بهبود زنتيكى تحمل به تنش

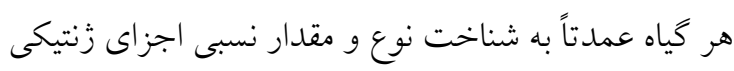
براى صفات مختلف در مواد گياهى تحت بررسى بستخى

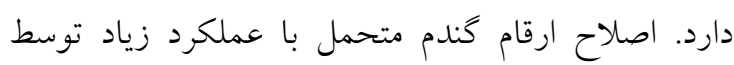
تلاقى لاينهاى والدى داراى تركيبيذيرى عمومى خوب و گزينش هيبر يدهاى مطلوب مورد توجه اصلاحگر ان است Sadeghzadeh- Ahari et al., 2015; Mohammadi and ) Roustaie, 2016 (طلاعات در مورد تركيبيذيرىهاى عمومى و خصوصى و نوع عمل زنها براى عملكرد و اجزاى عملكرد مىتواند امكان گزينش والدين مناسب براى اصلاح زنوتيٍٍ هاى مطلوب را افزايش دهد. طرحهاى دىآلل، مخصوصاً دى آللهاى يك طرفه به طور گستردهاى در Griffing, برنامهاى اصلاحى مورد استفاده قرار گرفتهاند 1956; Zobel and Talbert, 1984; Hallauer et al., 2010). محبوبيت اين روش به اين دليل است كه توانايى فراهم كردن اطلاعات زنتيكى در مورد تركيب عمومى (GCA) و الدين، تركيب يذيرى خصوصى (SCA) تاقى ها و ساير يارامترهاى زنتيكى مثل اجزاى واريانس و

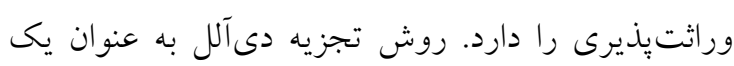
طرح مناسب براى گزينش والدى و كسب اطلاعات زنتيكى براى عملكرد و اجزاى عملكرد كندم توسط يزوهشخران

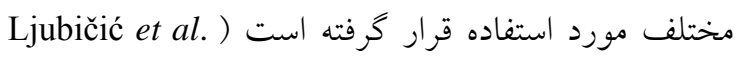
.(2014, 2017; Yao et al., 2014; Kumar et al., 2015 تجزيه باىيلات (GGE) در ابتدا براى تجزيه گرافيكى دادههاى آزمايش هاى جند محيطى بيشنهاد شد (Yan, 2001) ولى به همان اندازه در نمايش گر افيكى ساير انواع دادههاى دو طرفه با ساختار زنوتيب (Entry) × محك (Tester) مثل دادههاى تلاقى دى آلل موثر واقع شد ( Yan and Hunt,

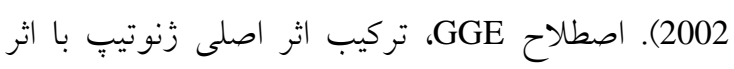


اجراى صحيح نمونهبردارى و حذف اثرات حاشيهاى، بوته-

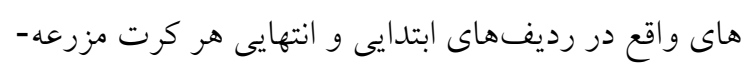

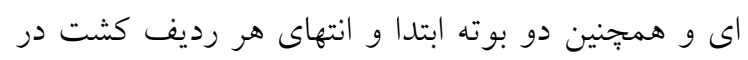

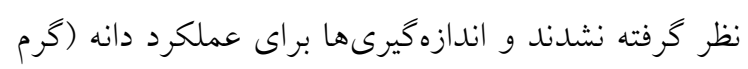

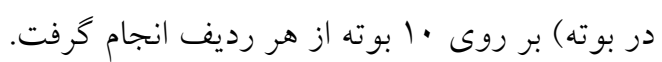

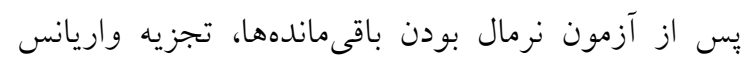
با استفاده از برنامه آمارى (Gomez and Gomez, 1984)

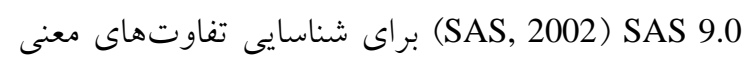

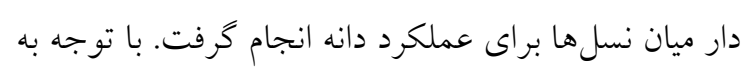

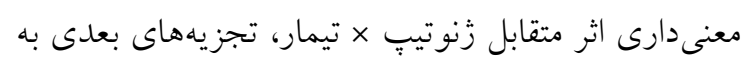
طور جداءانه در هر سطح تنش انجام شد.

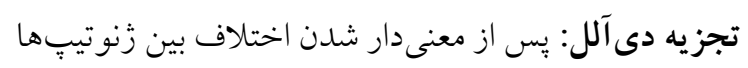

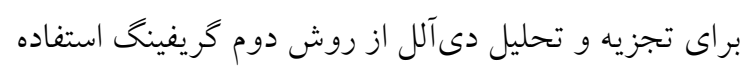

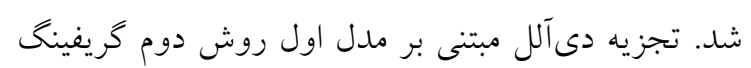

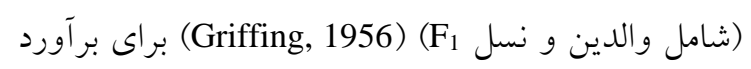
SCA و GCA

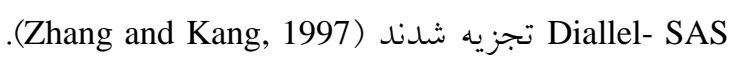
مدل خطى عمومى مبتنى بر دادههاى انفرادى عبارت است

$X_{i j k l}=\mu+\beta_{i}+g_{j}+g_{k}+s_{j k}+e_{i j k l} \quad$ (1) رابطه

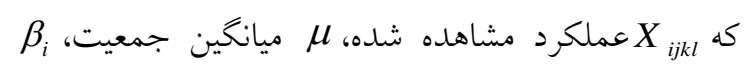

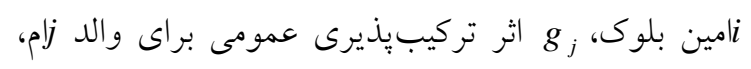

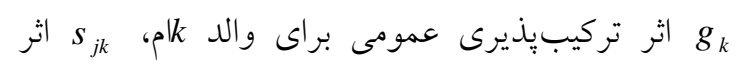
تركيبذيذيرى خصوصى براى تلاقى بين iامين و زامين

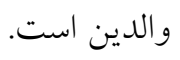

\section{تجزيه باى يُات دادههاى دى آلل}

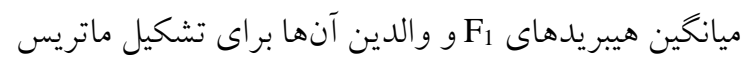

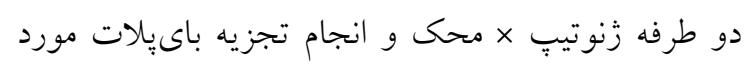

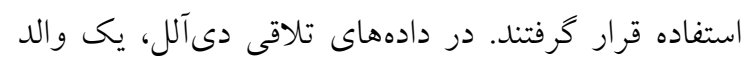

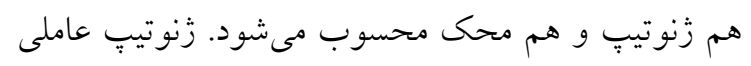

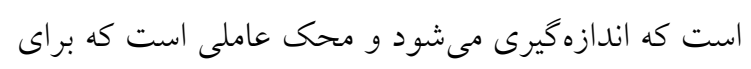

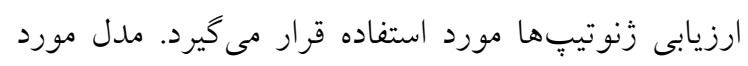

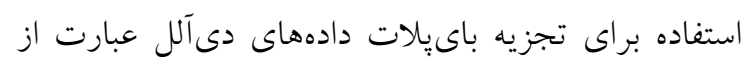

مواد و روشها

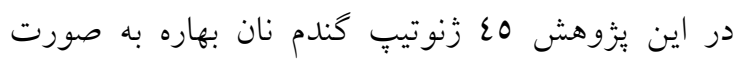

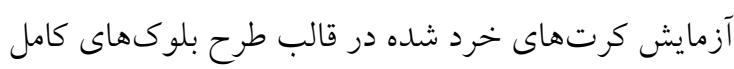

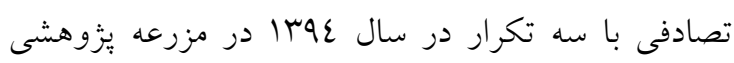

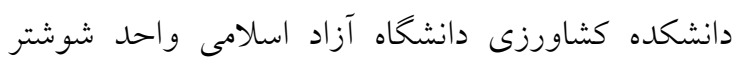

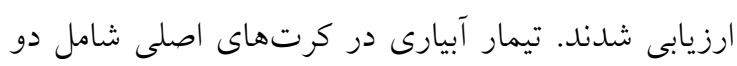

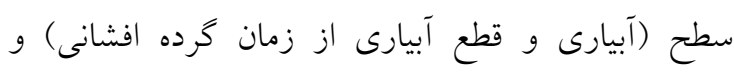

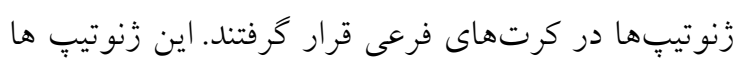

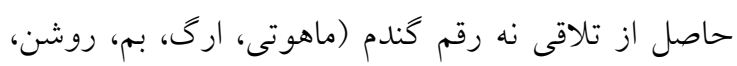

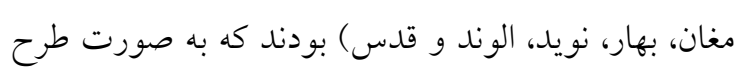

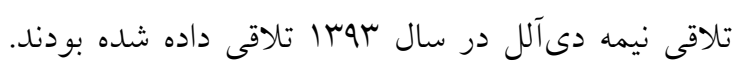

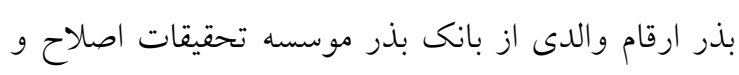

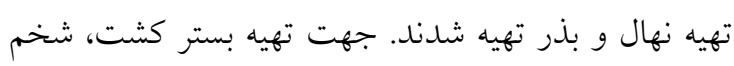

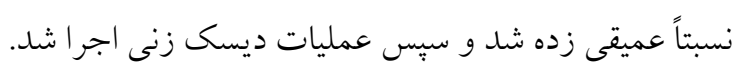

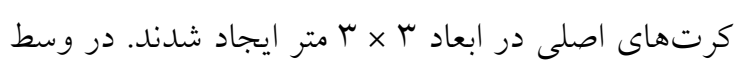

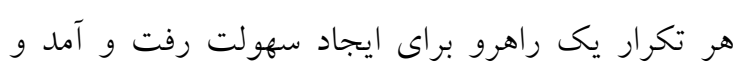

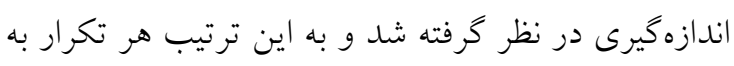

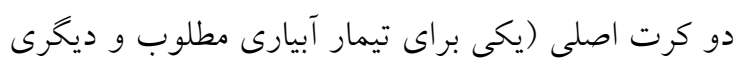

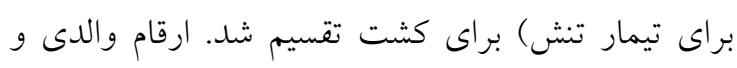

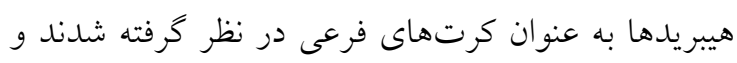

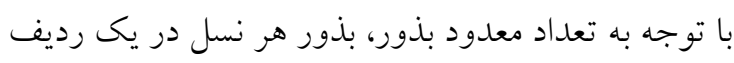

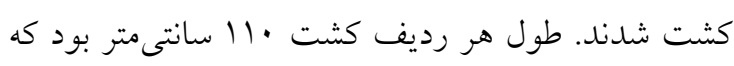

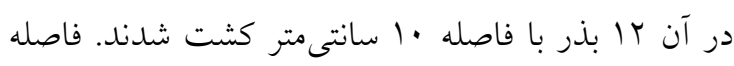

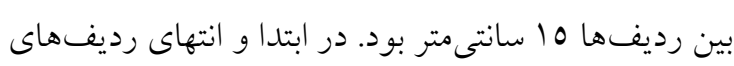

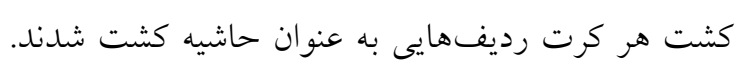

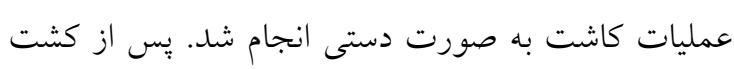
تا زمان كردهافشانى، آبيارى در هر دو شرايط تيمار آبيارى

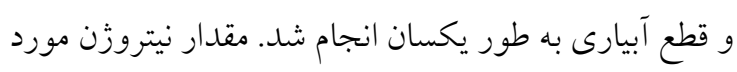

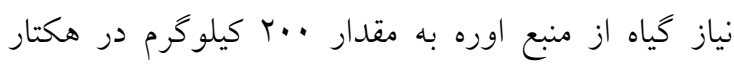

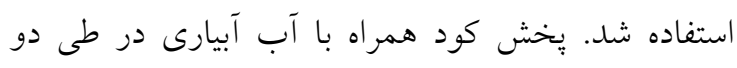

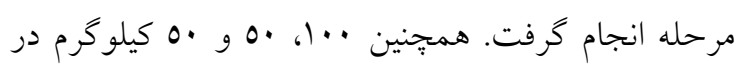

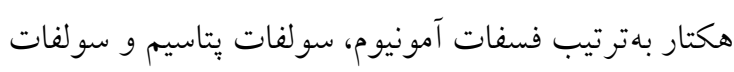

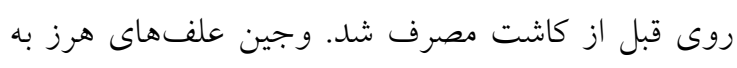

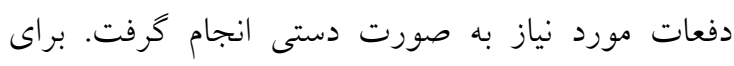


به عنوان ويزگ هاى زنوتيبها تعريف مىشوند. اثر SCA GCA با محك متوسط تعريف مىشود. بنابراين اثرهاى GCA

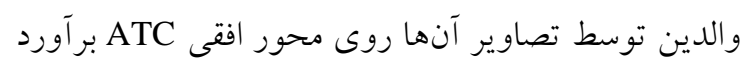

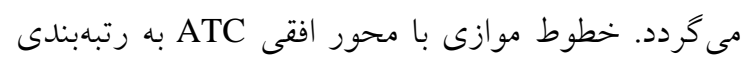
والدين از نظر اثرهاى GCA كمك مي كند.

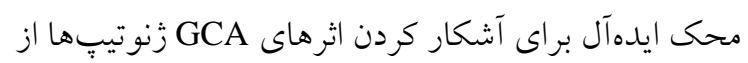
دو ويزَكى حداكثر توانايى تمايز زنوتيِها و و بيشترين

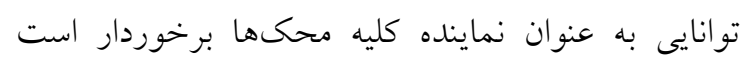
(Yan and Hunt, 2002; Yan and Kang, 2003) محك ايدهآل روى محور افقى ATC واقع است تا تصوير صفر بر روى محور عمودى ATC داشته باشد (بيشترين

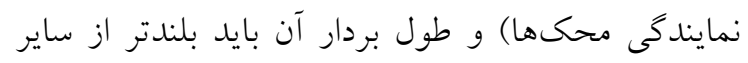

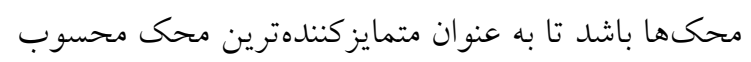

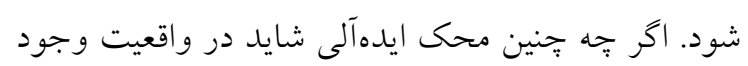

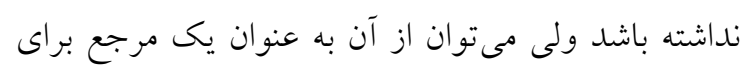

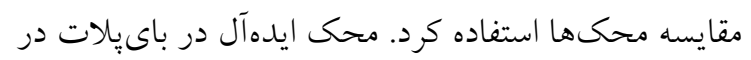

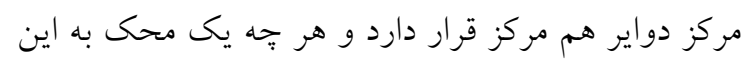
مركز نزديكتر باشد، مطلوبتر است.

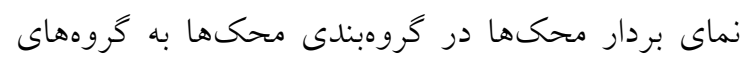

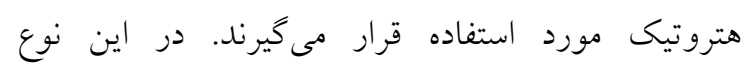
باىيلاتها طول بردار هر محكى معيارى از توانايى تمايز

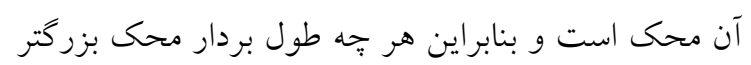

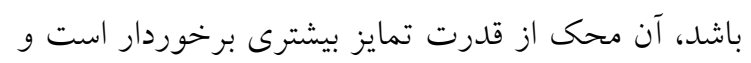

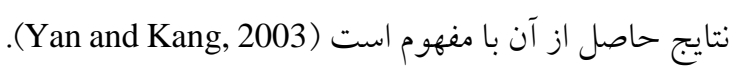

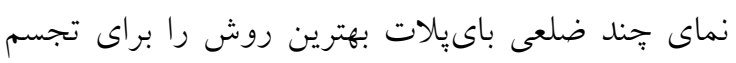

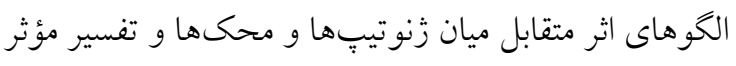

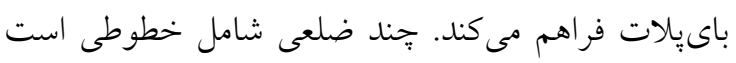

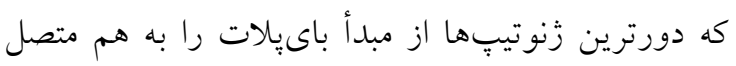

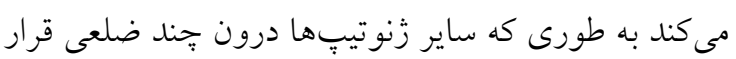

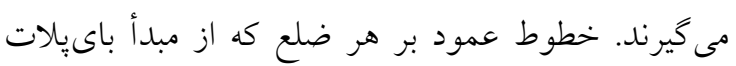

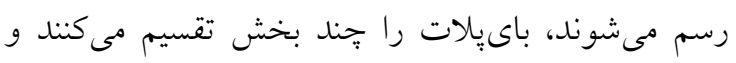

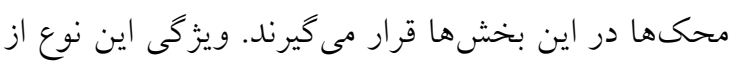

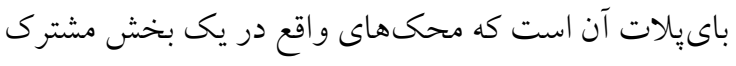

تجزيه به مولفههاى اصلى تصحيح شده بر اساس ميانخين محك است: $\hat{Y_{i j}}-\mu-\beta_{j}=g_{i 1} e_{1 j}+g_{i 2} e_{2 j}+\varepsilon_{i j} \quad$ (Y) رابطه كه در آن

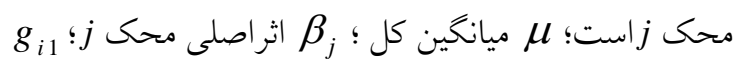
و g g g g $g_{i 2}$

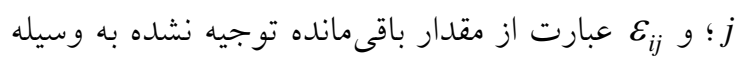

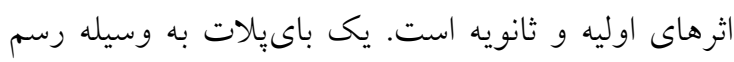
$g_{i 1}$

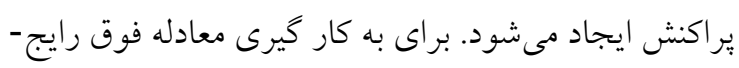
ترين روش، استفاده از تجزيه به مقادير منفرد (SVD) است: $\hat{Y_{i j}}-\mu-\beta_{j}=\lambda_{1} \xi_{i 1} \eta_{1 j}+\lambda_{2} \xi_{i 2} \eta_{2 j}+\varepsilon_{i j}$ (r) (r) كه در آن

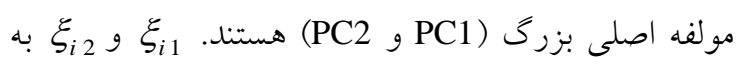

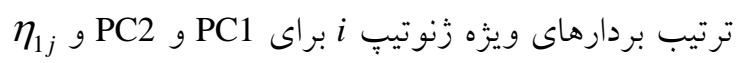
و

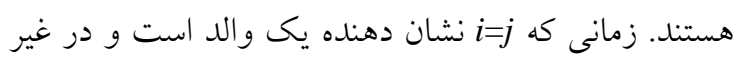
اين صورت، روش آمارى با جزئيات توسط يان و هانت ( Yan and (Hunt, 2002 توصيف شده است. تمامى باىيلاتهاى ارايه شده در مقاله

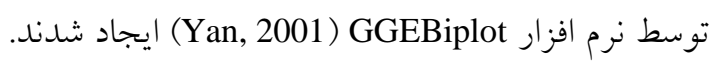
اثرات GCA و GCA والدين توسط تعريف مختصات محك متوسط (ATC: Average tester coordination)

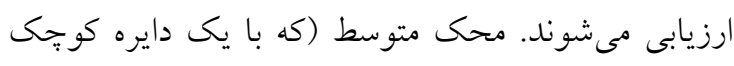

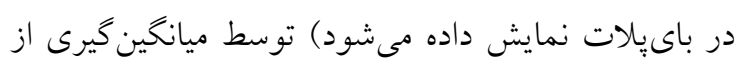

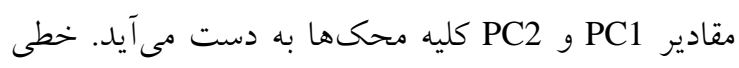

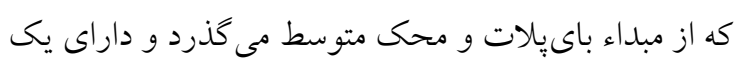

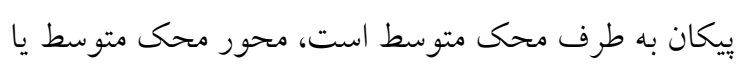

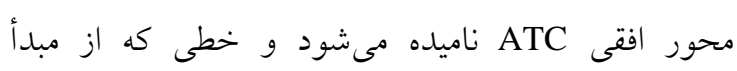

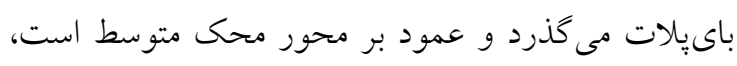

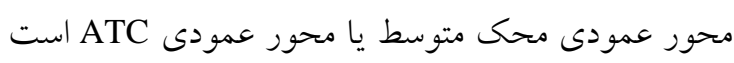
و GCA (Yan and Hunt, 2002; Yan and Kang, 2003) 
مورد نظر مىباشد، بنابراين اثرات GCA مثبت براى بهبود اين صفت ترجيح داده مىشوند (Ljubičić et al., 2017).

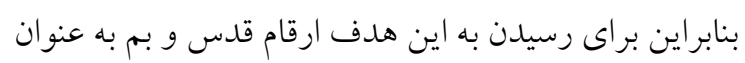

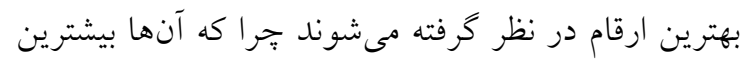
مقادير مثبت و معنى دار GCA را نشان دادند و عملكرد دانه را در تركيباتى كه وجود داشتند، افزايش دادند (جدول مَ).

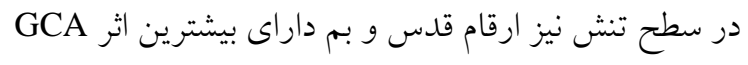

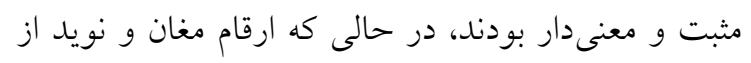

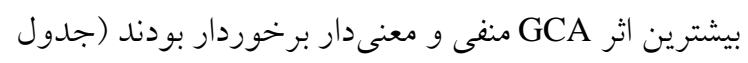

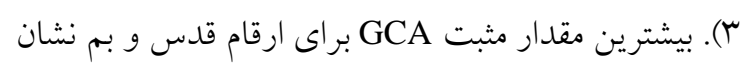

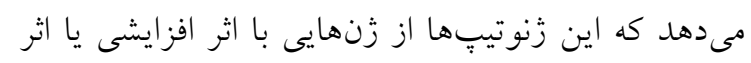

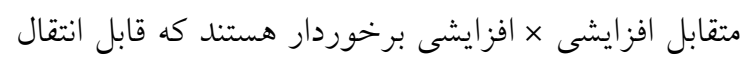

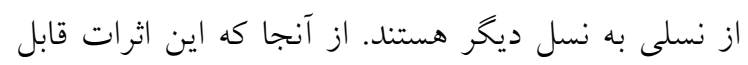

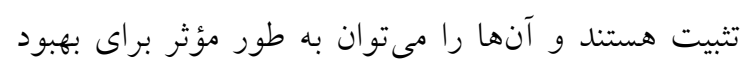

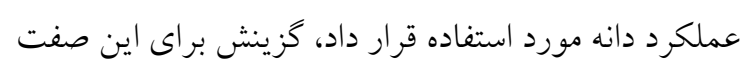
در نسل هاى در حال تفرق ابتدايى مى تواند كارآمد باشد.

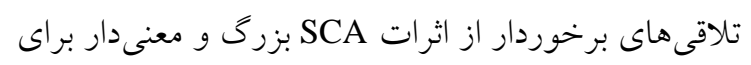

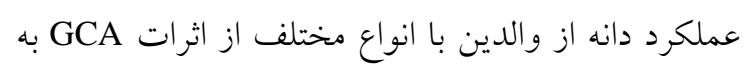
دست آمدند (جدول ؟). در سطح آبيارى مطلوب، بيشترين اثر SCA مثبت و معنى دار در تلاقىهاى نويد × مغان (كم

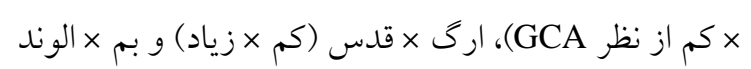

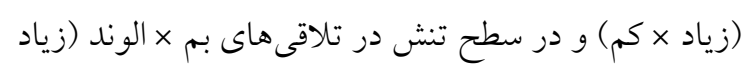

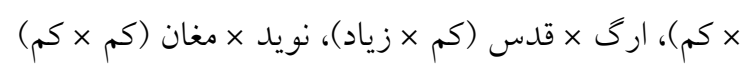

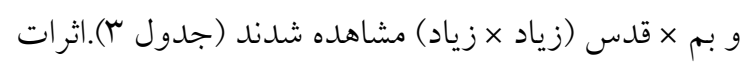

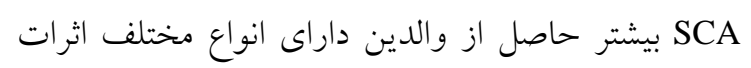
Raj and Kandalkar, ) توسط راج و كاندلكار GCA

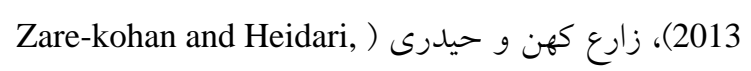

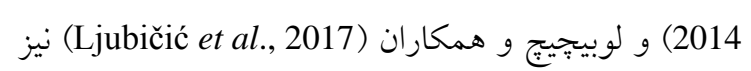

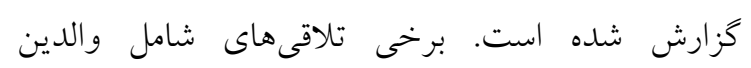

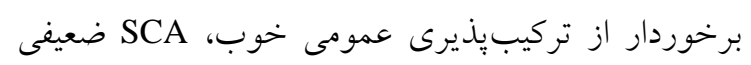

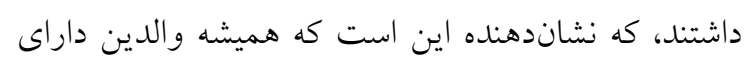

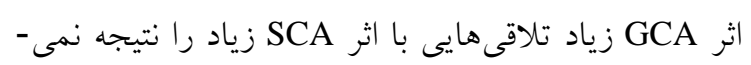
دهند. بيشترين اثر SCA منفى و معنى دار در سطح تيمار

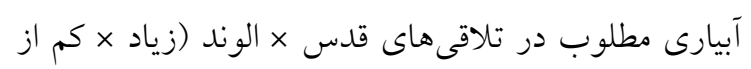

بهترين زوج تلاقى با زنوتيب رأس هند ضلعى موجود در آن بخش هستند (Yan and Hunt, 2002).

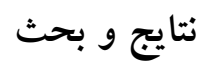

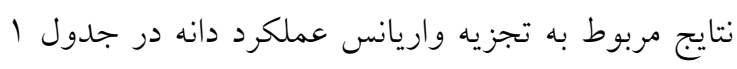

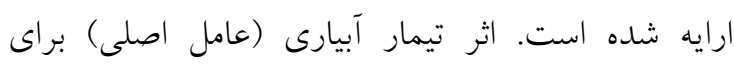

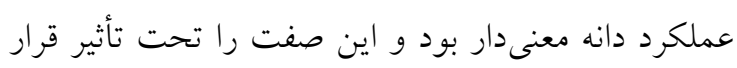

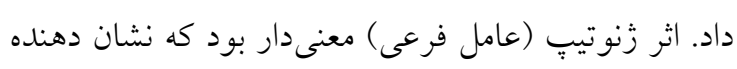

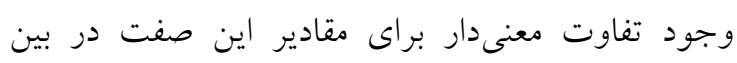

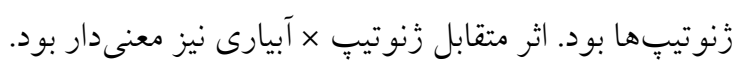

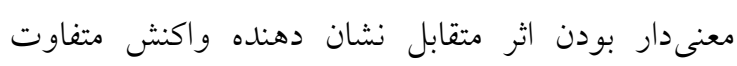

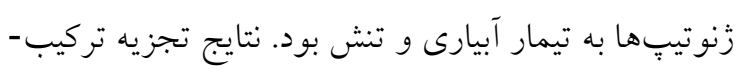

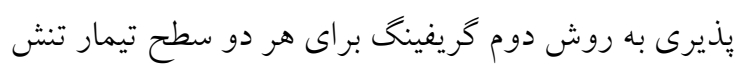

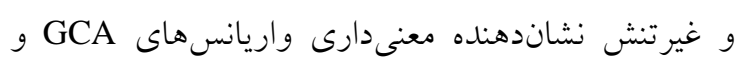

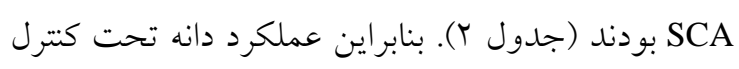

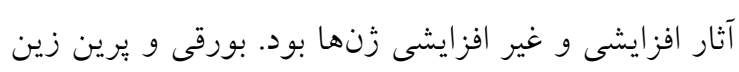
و و زارع كهن و حيدرى (Zorghi and Perenzin, 1994)

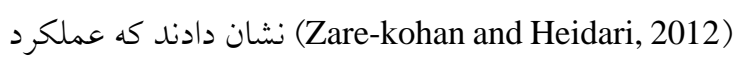
دانه تحت كنترل آثار افزايشى و غير افزايشى زنها بودند.

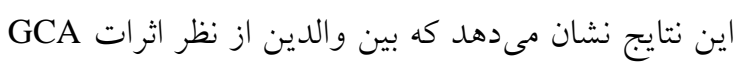
و بين حس تلاقى از نظر اثرات SCA تفاوت معنى دارى وجود

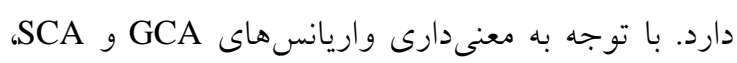

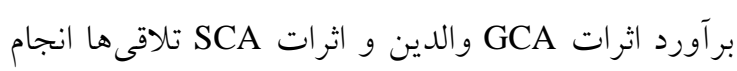
كرفت. بر آوردهاى تركيبيذيرى عمومى (GCA) لاينهاى والدى

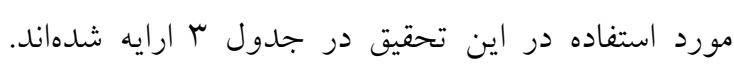

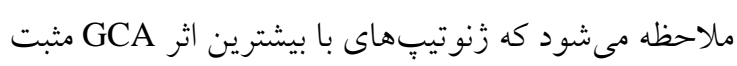

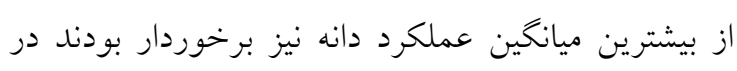

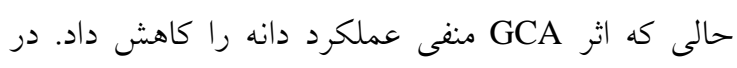
سطح تيمار آبيارى مطلوب، ارقام قدس و بم بيشترين مقادير

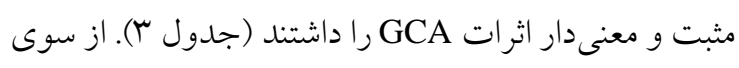
ديخر، ارقام مغان و ماهوتى به دليل برخوردارى از بيشترين

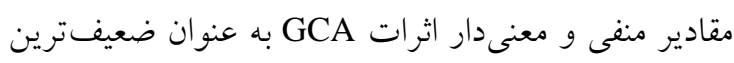

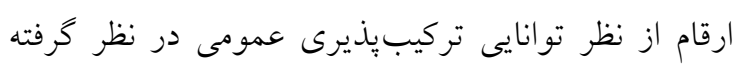

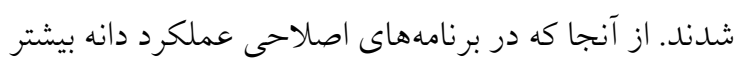


داراى اثر SCA زياد كه هر دو والد از اثرات GCA زياد برخوردار هستند مثل تلاقى بم × قدس اهميت دارند جرا كه شامل اثر متقابل افزايشى × افزايشى هستند. اين نوع اثر متقابل در نسل هاى انتهايى قابل تثبيت است و مىتوان از آن در برنامههاى اصلاحى آينده استفاده كرد. اثر SCA بالاى لئي حاصل از اين تلاقى نشان دهنده امكان بهبود زنتيكى عملكرد دانه از طريق روش گزينش شجرهاى است. اهميت اترات SCA بيشتر در تلاقى هايى با اثرات GCA زياد در كياهان زراعى خود كشن توسط جوشى و همكاران (Joshi (et al., 2004
نظر GCA) و بهار × قدس (كم × زياد) و در سطح تنش در تلاقى هاى قدس × نويد (زياد × كم)، ماهوتى × قدس (كم × زياد)، بهار × قدس (كم × زياد)، قدس × الوند (زياد × كم) و بم × مغان (زياد × كم) مشاهده شدند (جدول م). از آنجا كه اثر SCA معرف غالبيت و اثرات اييستازى است، آن را مىتوان براى كزينش لاينهاى هموزيخوس كه تفكيك متجاوز نشان مىدهند و همجينين براى توليد هيبريد كندم مورد استفاده قرار داد (Ljubičić et al., 2017). از آنجا كه موفقيت در كزينش در يك جمعيت به واريانس افزايشى بستخى دارد، استفاده از تلاقى هاى حاصل از و الدين داراى اثرات GCA زياد امكانيذير است. تلاقىهاى

جدول ا- تجزيه واريانس عملكرد دانه

Table 1. Analysis of variance for grain yield

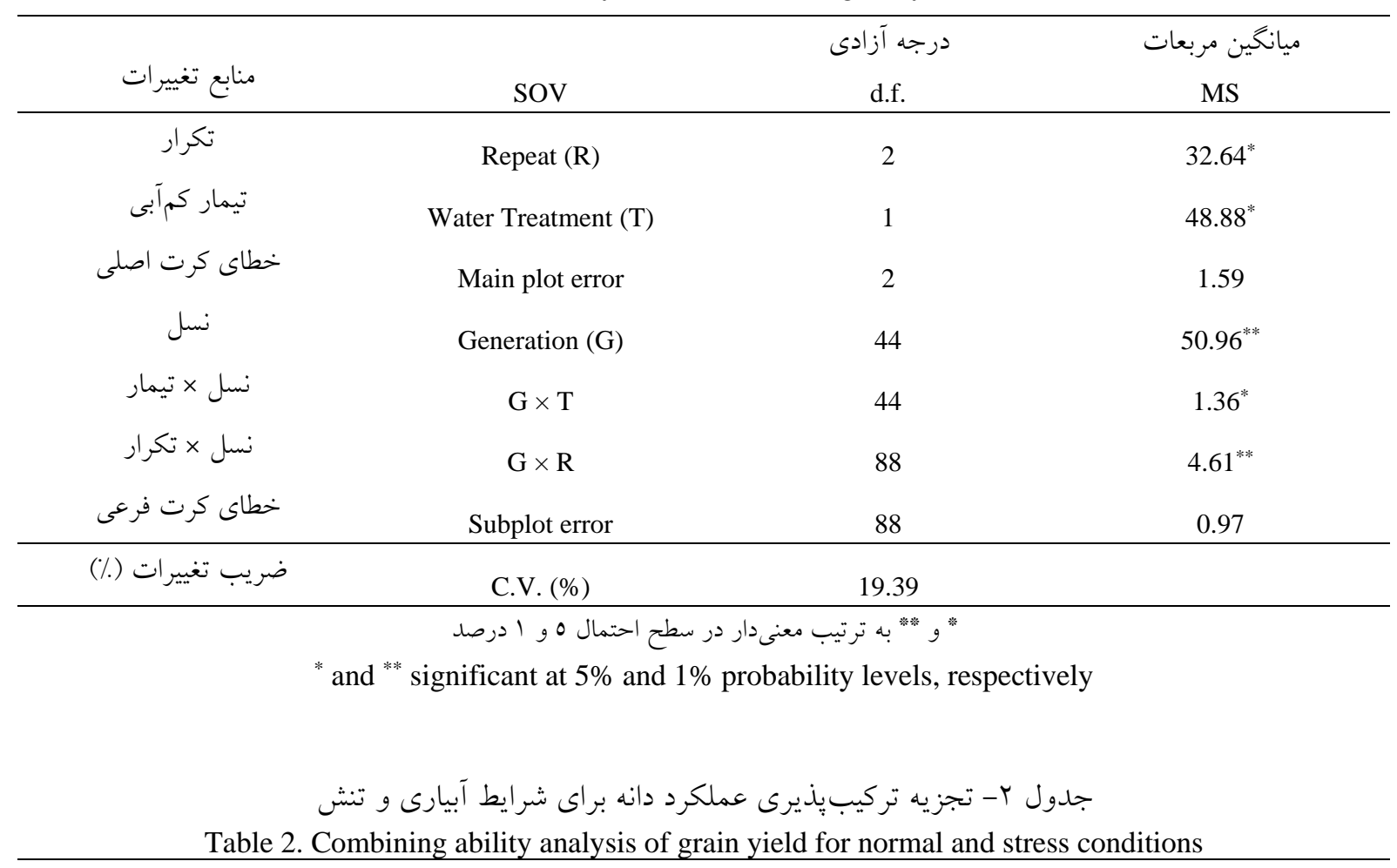

\begin{tabular}{|c|c|c|c|}
\hline \multirow{3}{*}{$\begin{array}{c}\text { منبع تغييرات } \\
\text { S.O.V. }\end{array}$} & \multirow{3}{*}{ درجه آزادى } & \multicolumn{2}{|c|}{ ميانخين مربعات (MS) } \\
\hline & & آبيارى & 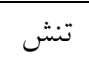 \\
\hline & & Normal & Stress \\
\hline GCA & 8 & $7.85^{* *}$ & $5.33^{* *}$ \\
\hline SCA & 36 & $9.92^{* *}$ & $8.28^{* *}$ \\
\hline E & 88 & 0.91 & 0.98 \\
\hline
\end{tabular}


جدول ب- مقادير ميانخين عملكرد دانه و برآوردهاى GCA و SCA و الدين و تلاقى ها

Table 3. Grain yield mean values and estimates of GCA and SCA of parents and their crosses

\begin{tabular}{|c|c|c|c|c|}
\hline \multirow[b]{2}{*}{ زَنوتي" } & \multicolumn{2}{|c|}{ شرايط بدون تنش Non- stress condition } & \multicolumn{2}{|c|}{ شرايط تنش Stress condition } \\
\hline & $\begin{array}{c}\text { ميانخين عملكرد دانه } \\
\text { (كرم/بوته) } \\
\text { Grain yield mean } \\
\text { (g/plant) }\end{array}$ & $\begin{array}{c}\text { SCA و GCA مقادير } \\
\text { GCA and SCA values }\end{array}$ & ميانخين عملكرد دانه (كرم/بوته) & $\begin{array}{c}\text { SCA و GCA مقادير } \\
\text { GCA and SCA values }\end{array}$ \\
\hline Bahar (1) & 9.58 & $0.07^{\mathrm{ns}}$ & 8.55 & $0.17^{\mathrm{ns}}$ \\
\hline $\operatorname{Arg}(2)$ & 3.68 & $0.17^{\mathrm{ns}}$ & 2.81 & $0.24^{\mathrm{ns}}$ \\
\hline Mahoti (3) & 3.85 & $-0.74^{* *}$ & 2.86 & $-0.51^{\mathrm{ns}}$ \\
\hline Bam (4) & 6.26 & $1.11^{* *}$ & 5.15 & $0.97^{* *}$ \\
\hline Roshan (5) & 7.39 & $-0.18^{\mathrm{ns}}$ & 7.32 & $-0.03^{\mathrm{ns}}$ \\
\hline Ghods (6) & 10.67 & $1.49^{* *}$ & 7.64 & $1.12^{* *}$ \\
\hline Navid (7) & 2.54 & $-0.51^{\mathrm{ns}}$ & 1.50 & $-0.60^{*}$ \\
\hline Moghan (8) & 5.85 & $-1.16^{* *}$ & 5.64 & $-0.76^{*}$ \\
\hline Alvand (9) & 8.74 & $-0.25^{\mathrm{ns}}$ & 4.69 & $-0.59^{\mathrm{ns}}$ \\
\hline $1 \times 2$ & 6.84 & $1.04^{\mathrm{ns}}$ & 6.70 & $1.57^{\mathrm{ns}}$ \\
\hline $1 \times 3$ & 7.39 & $2.50^{* *}$ & 7.33 & $2.97^{* *}$ \\
\hline $1 \times 4$ & 6.70 & $-0.04^{\mathrm{ns}}$ & 5.09 & $-0.75^{\mathrm{ns}}$ \\
\hline $1 \times 5$ & 4.27 & $-1.17^{\mathrm{ns}}$ & 2.81 & $-2.02^{*}$ \\
\hline $1 \times 6$ & 2.81 & $-4.32^{* *}$ & 2.87 & $-3.13^{* *}$ \\
\hline $1 \times 7$ & 3.06 & $-2.05^{*}$ & 2.50 & $-1.77^{\mathrm{ns}}$ \\
\hline $1 \times 8$ & 2.92 & $-1.54^{\mathrm{ns}}$ & 1.56 & $-2.55^{*}$ \\
\hline $1 \times 9$ & 3.22 & $-2.14^{* *}$ & 2.97 & $-1.30^{\mathrm{ns}}$ \\
\hline $2 \times 3$ & 8.44 & $3.45^{* *}$ & 7.67 & $3.24^{* *}$ \\
\hline $2 \times 4$ & 4.40 & $-2.44^{* *}$ & 4.72 & $-1.20^{\mathrm{ns}}$ \\
\hline $2 \times 5$ & 2.96 & $-2.57^{* *}$ & 2.66 & $-2.24^{*}$ \\
\hline $2 \times 6$ & 13.22 & $6.00^{* *}$ & 11.49 & $5.41^{* *}$ \\
\hline $2 \times 7$ & 5.06 & $-0.15^{\mathrm{ns}}$ & 3.21 & $-1.12^{\mathrm{ns}}$ \\
\hline $2 \times 8$ & 2.35 & $-2.21^{*}$ & 1.53 & $-2.65^{* *}$ \\
\hline $2 \times 9$ & 6.78 & $1.31^{\mathrm{ns}}$ & 6.09 & $1.74^{\mathrm{ns}}$ \\
\hline $3 \times 4$ & 4.89 & $-1.03^{\mathrm{ns}}$ & 3.10 & $-2.05^{*}$ \\
\hline $3 \times 5$ & 4.40 & $-0.21^{\mathrm{ns}}$ & 3.42 & $-0.72^{\mathrm{ns}}$ \\
\hline $3 \times 6$ & 2.67 & $-3.63^{* *}$ & 1.87 & $-3.43^{* *}$ \\
\hline $3 \times 7$ & 3.75 & $-0.54^{\mathrm{ns}}$ & 4.22 & $0.63^{\mathrm{ns}}$ \\
\hline $3 \times 8$ & 3.86 & $0.21^{\mathrm{ns}}$ & 4.70 & $1.28^{\mathrm{ns}}$ \\
\hline $3 \times 9$ & 4.25 & $-0.30^{\mathrm{ns}}$ & 3.27 & $-0.31^{\mathrm{ns}}$ \\
\hline $4 \times 5$ & 3.31 & $-3.17^{* *}$ & 2.99 & $-2.64^{* *}$ \\
\hline $4 \times 6$ & 11.47 & $3.29^{* * *}$ & 11.10 & $4.30^{* *}$ \\
\hline $4 \times 7$ & 9.77 & $3.61^{* *}$ & 7.85 & $2.77^{* * *}$ \\
\hline $4 \times 8$ & 2.75 & $-2.75^{* *}$ & 1.85 & $-3.06^{* *}$ \\
\hline $4 \times 9$ & 12.01 & $5.60^{* *}$ & 10.72 & $5.64^{* *}$ \\
\hline $5 \times 6$ & 10.65 & $3.78^{* *}$ & 7.74 & $1.94^{*}$ \\
\hline $5 \times 7$ & 7.37 & $2.52^{* * *}$ & 6.86 & $2.80^{* * *}$ \\
\hline $5 \times 8$ & 2.69 & $-1.51^{\mathrm{ns}}$ & 3.04 & $-0.85^{\mathrm{ns}}$ \\
\hline $5 \times 9$ & 3.03 & $-2.07^{*}$ & 2.43 & $-1.63^{\mathrm{ns}}$ \\
\hline $6 \times 7$ & 3.14 & $-3.39^{* * *}$ & 1.77 & $-3.45^{* * *}$ \\
\hline $6 \times 8$ & 5.07 & $-0.81^{\mathrm{ns}}$ & 5.12 & $0.05^{\mathrm{ns}}$ \\
\hline $6 \times 9$ & 1.64 & $-5.14^{* *}$ & 2.18 & $-3.05^{* *}$ \\
\hline $7 \times 8$ & 9.88 & $6.00^{* * *}$ & 8.54 & $5.20^{* * *}$ \\
\hline $7 \times 9$ & 2.73 & $-2.04^{*}$ & 2.40 & $-1.09^{\mathrm{ns}}$ \\
\hline $8 \times 9$ & 1.53 & $-2.60^{* *}$ & 1.01 & $-2.33^{*}$ \\
\hline LSD 5\% & 2.51 & & 2.26 & \\
\hline
\end{tabular}

ns: Non-significant; * and ** Significant at 0.05 and 0.01 probability levels, respectively 
هاى بعدى قرار داشتند (شكل ع). ترتيب و علامت GCA

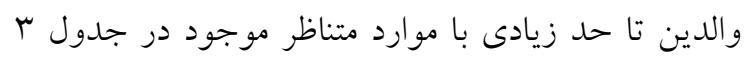

مطابقت داشتند. - ماتر

از آنجا كه باىيلات حاوى GCA و SCA است و و به دليل اين كه محور افقى ATC اثرهاى GCA والدين را نشان مى دهد، بنابراين محور عمودى ATC كه نسبت به اثرهاى

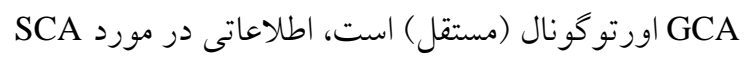

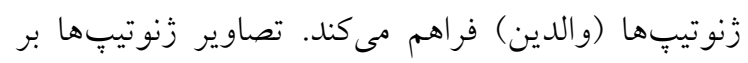
روى محور عمودى ATC اثرات SCA والدين را برآورد

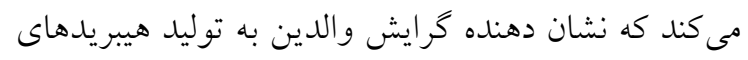
برتر با محكىهاى خاص است. در شر ايط غير تنش، محكهها هم در بالاى محور افقى ATC (ارگ، بم، روشن و مغان) و

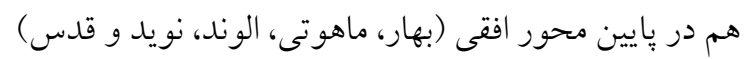

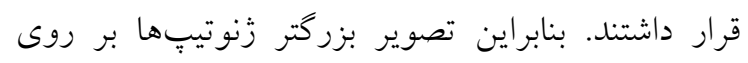

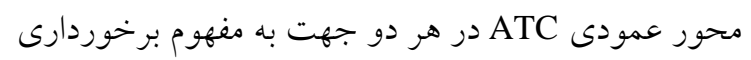

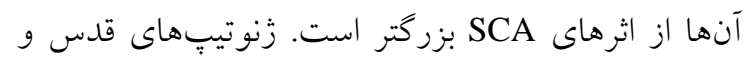

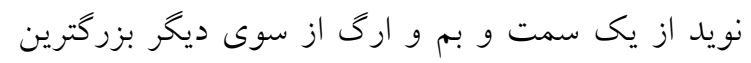

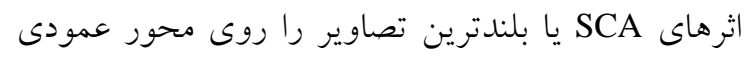
SCA داشتند. ماهوتى و بهار از كمترين ميزان ATC

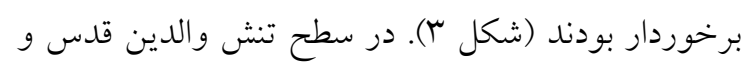

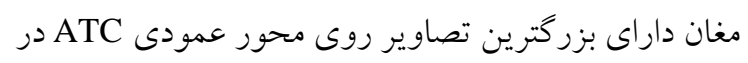

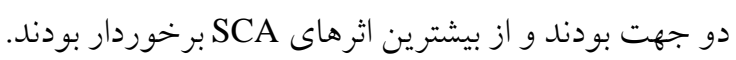
در سطح تنش نيز زنوتيِّهاى ماهوتى و بهار كمترين ميزان SCA در سطح غيرتنش، محك قدس بهترين محكى بود و اثر انر

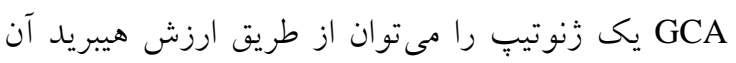
والد با محكى قدس ارزيابى كرد (شكل 0). در مقابل بهار

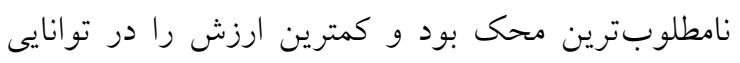

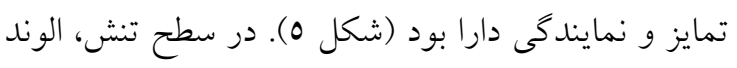

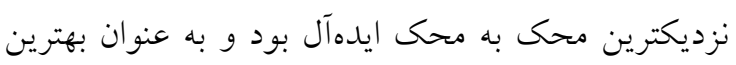
محكى انتخاب شد. از سوى ديكر محكى مغان دورترين

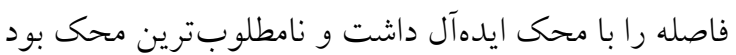

اثرات SCA بيشتر كه در تلاقى هايى با يك والد با اثر GCA زياد و يك والد با اثر GCA كم حاصل شده است، نشان دهنده دخالت اثر افزايشى × غالبيت در بروز صفت است

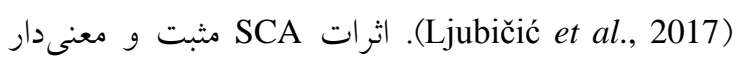
مشاهده شده در تلاقىهاى نويد × مغان (در هر دو سطح

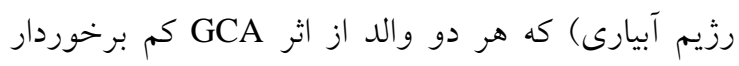

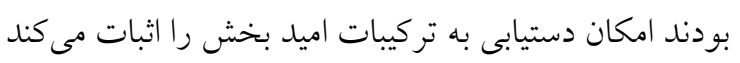

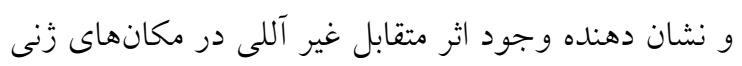

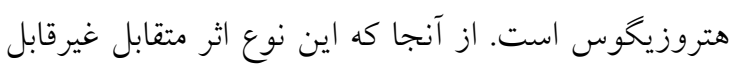

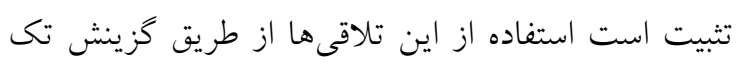

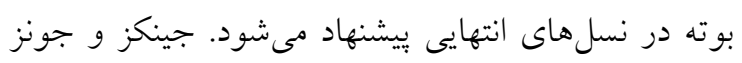
نشان دادند كه در لاينهاى (Jinks and Jones, 1958) والدى با GCA كم، هتروزيخوسيتى ناشى از اثرات غير افزايشى مسؤول پاسخ بيشتر به محيط هستند.

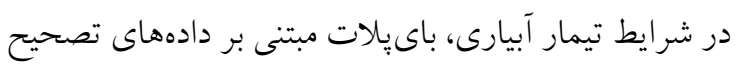

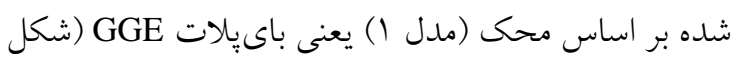

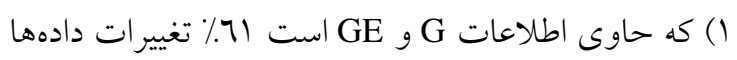

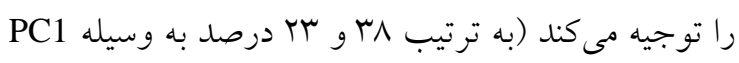

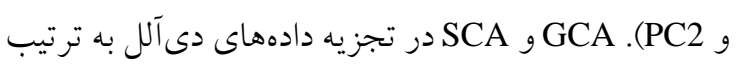
متناظر با GE و GE در تجزيه دادههاى زنوتيب × محيط

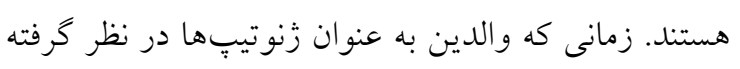
مىشوند با حروف ايتاليك نمايش داده مىشوند و اخر به ونه

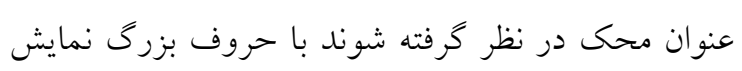

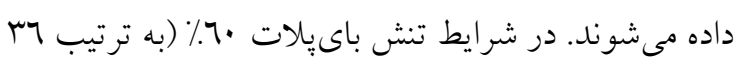

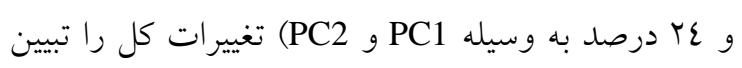
كرد (شكل r). در سطح آبيارى والد قدس از بيشترين GCA مثبت

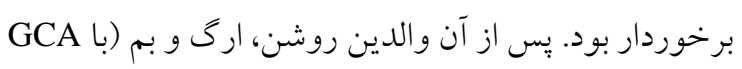

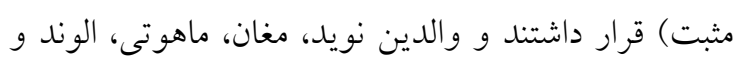

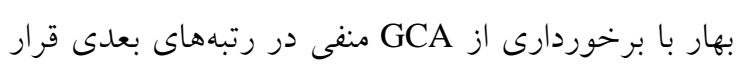

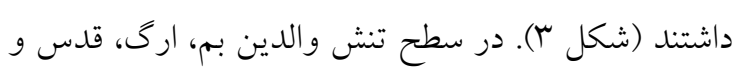

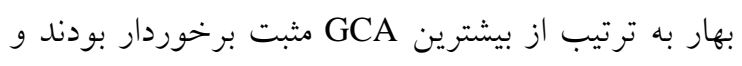

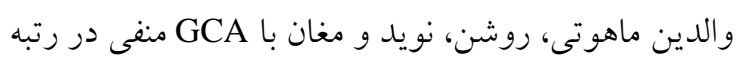




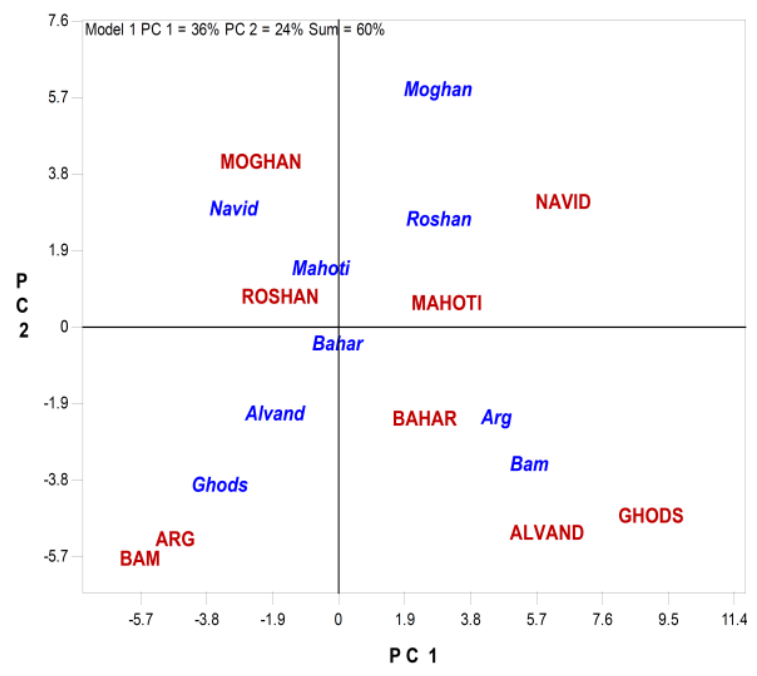

شكل r- باى يلات دادهاى دى آلل عملكرد دانه كُندم در

$$
\text { شرايط تنش }
$$

Figure 2. Diallel data biplot for grain yield in stress condition

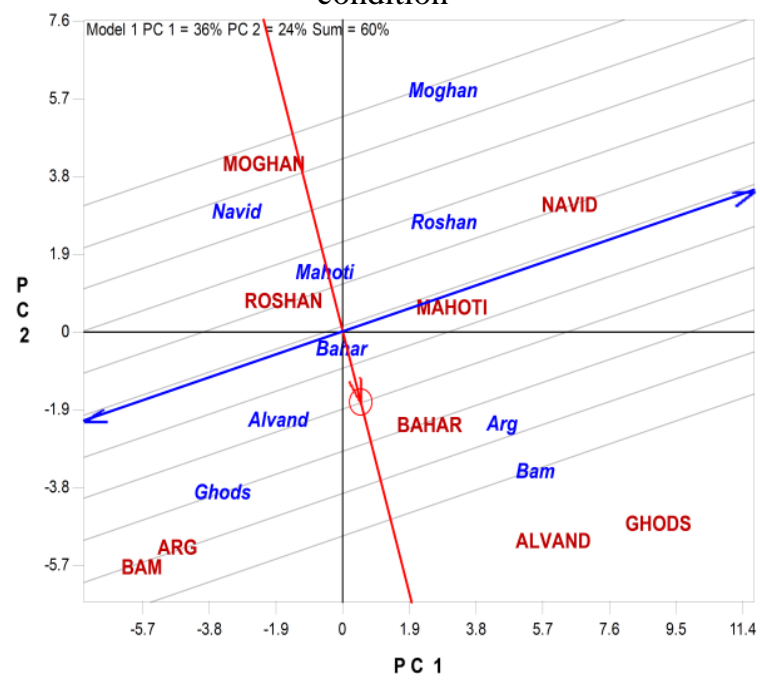

شكل ع- نماى مختصات متوسط باى يلات دادههاى دى آلل

$$
\text { عملكرد گندم در شرايط تنش }
$$

Figure 4. ATC view of diallel data biplot for grain yield in stress condition

نويد اثر متقابل مثبت با زنوتيبٍهاى روشن، ارگ، بم و مغان داشتند. اين الكوى اثر متقابل به وضوح بروز هتروزيس را در تلاقى هاى (روشن، ارگ و بم) × (قدس و نويد) نشان

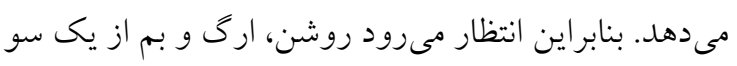
و قدس و نويد دو گروه هتروتيك مختلف باشند (شكل V V). در سطح تنش انتظار مىرود دو گروه بم و ارگ به عنوان يك گروه و قدس و الوند به عنوان گروه ديخر بهترين هيبريدها را نتيجه دهند (شكل م).

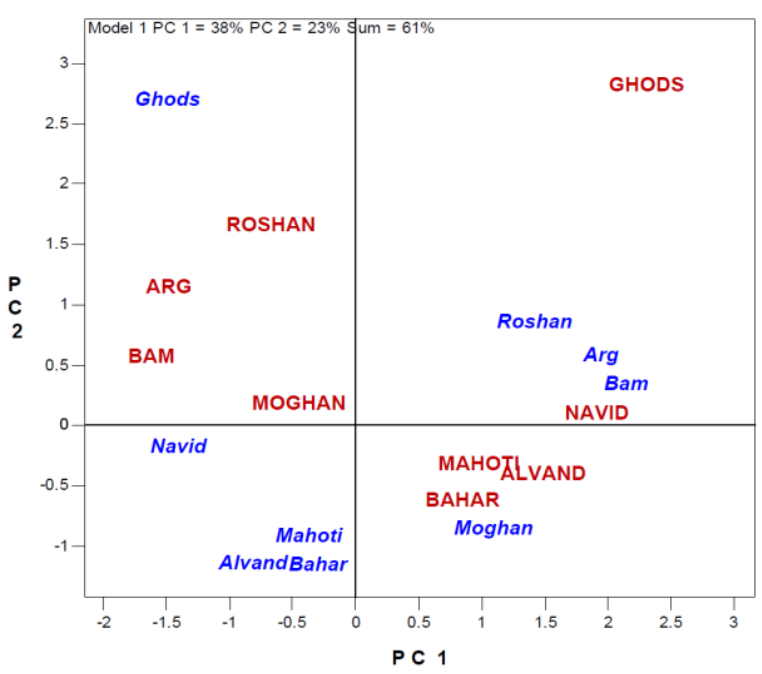

شكل 1- باى يلات دادههاى دى آلل عملكرد دانه گُندم در

$$
\text { شرايط آبيارى }
$$

Figure 1. Diallel data biplot for grain yield in normal condition

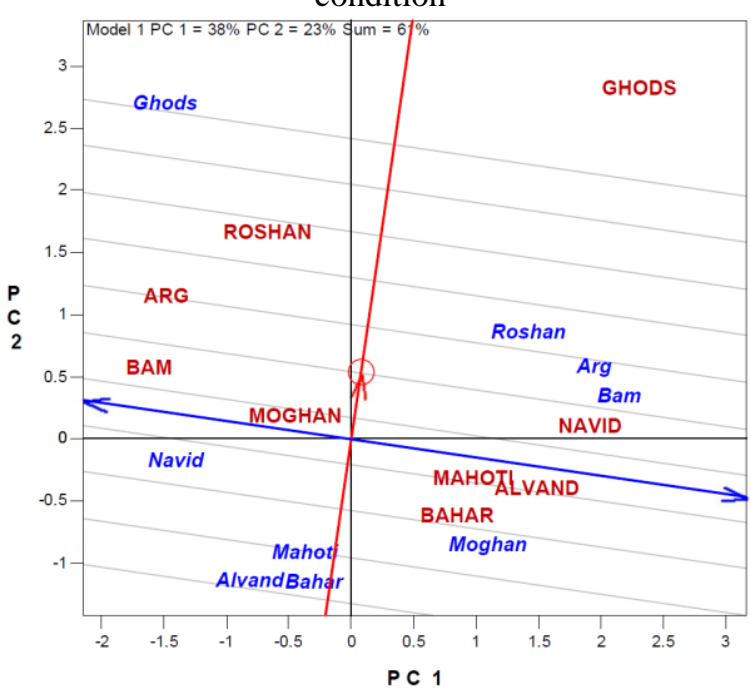

شكل "- نماى مختصات متوسط باى يلات دادههاى دى آلل

$$
\text { عملكرد كندم در شرايط آبيارى }
$$

Figure 3. ATC view of diallel data biplot for grain yield in normal condition

$$
\begin{aligned}
& \text { در سطح تيمار آبيارى طول بردارهاى مربوط به محكهاى } \\
& \text { مغان، ماهوتى و بهار كو جكى بودند و بنابراين قدرت تمايز } \\
& \text { كمترى داشتند (شكل V). در اين شكل با در نظر گرفتن } \\
& \text { محكهاى برخوردار از طول بردار بزرگتر، دو گروه از }
\end{aligned}
$$

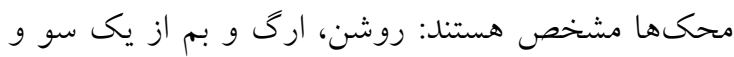

$$
\begin{aligned}
& \text { قدس و نويد از سمت ديخر. محكهاى روشن، ارگ و بم } \\
& \text { داراى اثر متقابل مثبت با زنوتيبٌهاى قدس، نويد، الوند، } \\
& \text { ماهوتى و بهار بودند. به طور مشابه، محكىهاى قدس و }
\end{aligned}
$$




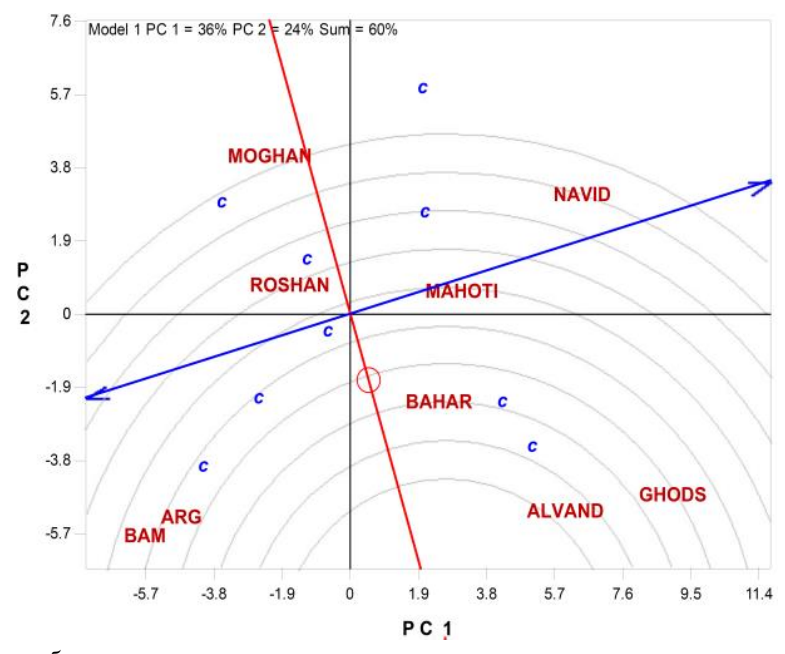

شكل 7- مقايسه والدين به عنوان محكهها با محكى ايدهآل

$$
\text { در شرايط تنش }
$$

Figure 6. Comparison of parents as testers with ideal

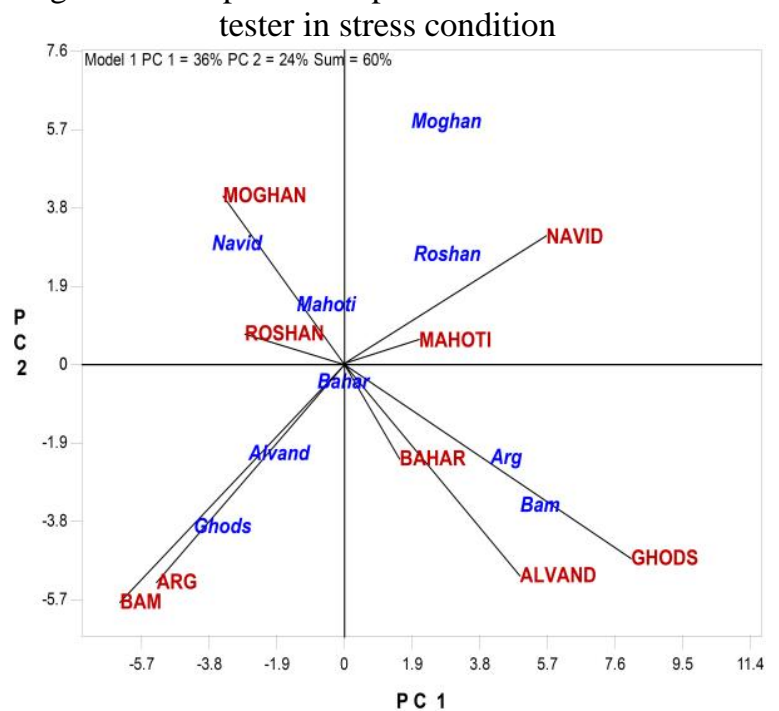

شكل ^- نماى بردار محك باى يلات دادههاى دى آلل گندم

$$
\text { در شرايط تنش باي نيالت }
$$

Figure 8. Tester vector view for wheat diallel data in stress condition

ترتيب از GCA و SCA بالايى برخوردار هستند و توانايى

$$
\text { توليد هيبريد برتر براى عملكرد دانه را دارند. }
$$

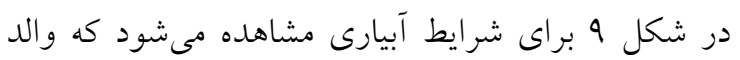
قدس بهترين زوج تلاقى با محكهاى روشن، ارگ، بم و

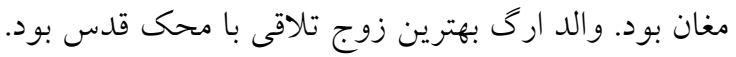

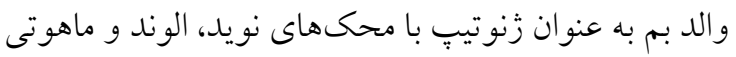
بهترين زوج تلاقى بود. محك بهار در بخش مغان قرار كرفت كه نشان مىدهد مغان بهترين زوج تلاقى با بهار بهار بهار

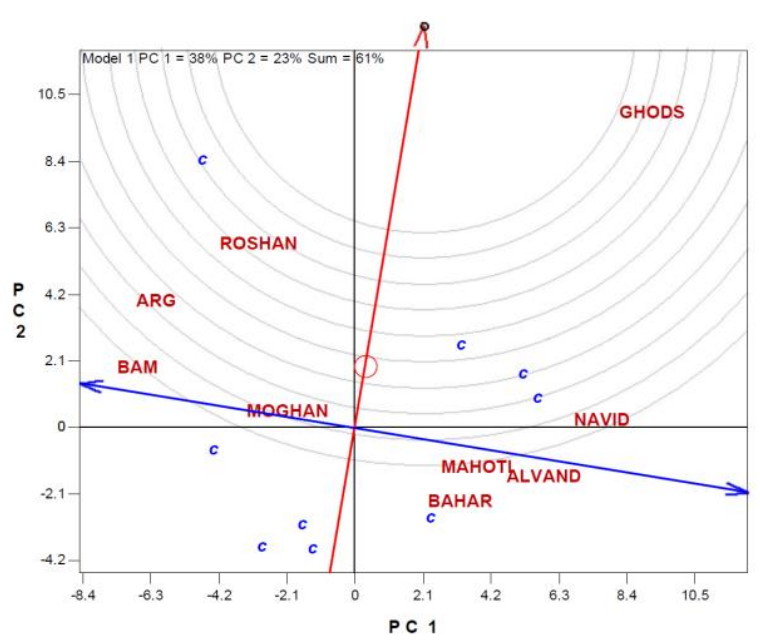

شكل 0- مقايسه والدين به عنوان محكها با محكى ايدهآل

$$
\text { در شرايط آبيارى }
$$

Figure 5. Comparison of parents as testers with ideal tester in normal condition

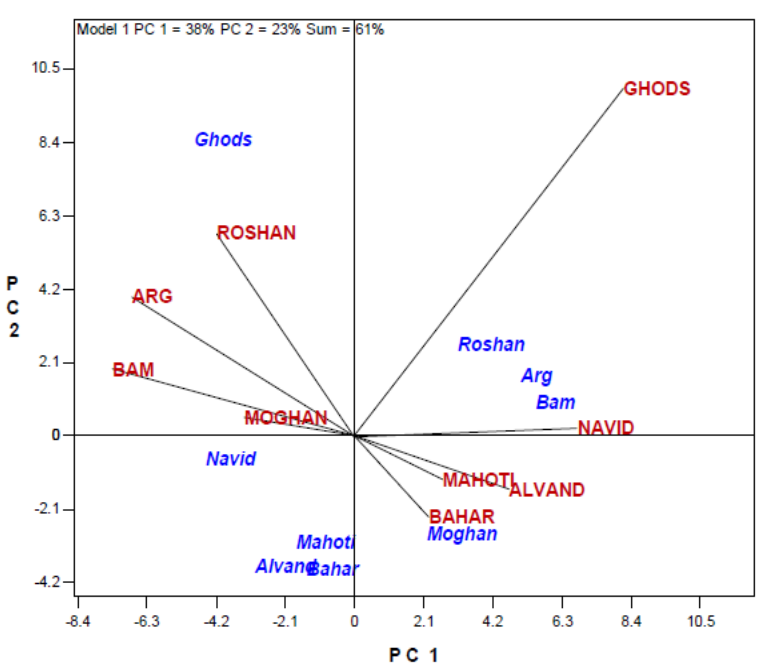

شكل V- نماى بردار محك باى يلات دادههاى دى آلل گندم

$$
\text { در شرايط آبيارى }
$$

Figure 7. Tester vector view for wheat diallel data in normal condition

محكىهاى مغان و نويد با وجود طول بردار بلند نسبت به

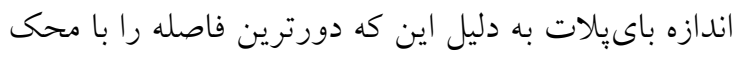

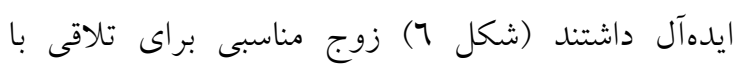
زنوتيڤها نبودند. از آنجايى كه ارزش يك هيبريد برتر

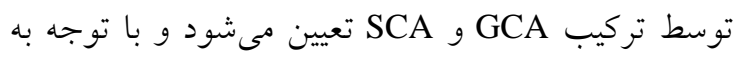

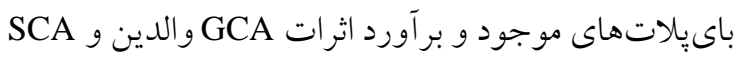
تلاقى ها در جدولهاى ع و 0، مشاهده مىشود كه والدين تشكيل دهنده خروههاى هتروتيك و هيبريدهاى آنها به 
باىيلات، شناسايى والدين را از طريق دو بعد GCA و SCA ممكن است باىيلات تمام تنوع موجود در دادهها را توجيه نكند ولى مىتوان اطمينان داشت كه باىيلات مؤلفههاى اصلى اول و دوم مهمترين الخوهاى موجود در دادهها را نمايش مىدهد (Yan and Hunt, 2002). كارايى روش لم باىيلات در تفسير دادهاى دىآلل در گُندم اثبات شده Yan and Hunt, 2002; Mostafavi and Zabet, ) است 2013). مقايسه نتايج تجزيه متداول با نتايج گرافيكى مطابقت خوب بين اين دو روش را نشان داد. با توجه به برخوردارى روش باىيلات از مزاياى تفسير سريعتر و سادهتر، استغاده از اين روش توصيه مى شود. با توجه به معنى دارى واريانسهاى GCA و SCA و بالا بودن نسبت واريانس GCA به SCA، عملكرد دانه در هر دو سطح تنش و غير تنش تحت كنترل آثار افزايشى و غير

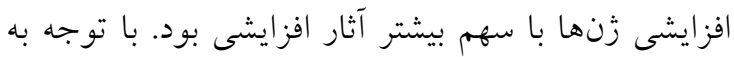
وجود تنوع زنتيكى بين ارقام و هيبريدها براى GCA و امكان گزينش زنوتيڤهاى برتر جهت افزايش عملكرد دانه در شرايط تنش و غير تنش وجود دارد. بنابراين مىتوان ابتدا با انتخاب زَنوتيٍٍ هاى برتر از عمل

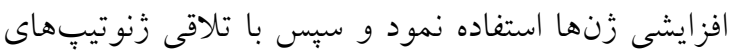
انتخابى از عمل غير افزايشى زنها نيز استفاده كرد. به طور كلى با توجه به نتايج كسب شده، ارقام بم، قدس و ارگ علاوه بر تحمل به تنش و حفظ عملكرد در شرايط تنش خشكى توانايى انتقال اين ويز گیىها به هيبريدها را نيز داشتند و از آنها مىتوان در برنامههاى اصلاحى براى بهبود تحمل به تنش استفاده كرد. در صورتى كه تركيبيذيرى

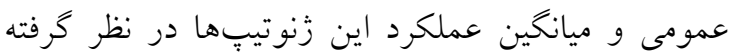
شوند، از اين سه والد مى توان در برنامه توليد هيبريد براى بهبود ارقام داراى عملكرد دانه بيشتر استفاده كرد. از سوى ديخر در صورتى كه تركيبيذيرى خصوصى و ميانگين عملكرد تلاقىها در نظر گرفته شوند، نسل F1 تلاقى ها نظير ارگ × قدس، بم × الوند، بم × قدس و نويد × مغان براى بهبود عملكرد دانه موثر هستند.
است. در بخش هاى نويلد، الوند و بهار هيج محكى قرار

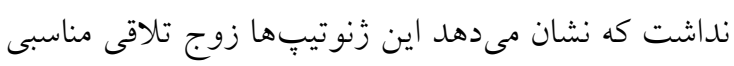
با هيج يك از زنوتيبٍها نبودند (شكل 9). در سطح تنش در بخش مغان محكى نويد قرار داشت كه نشان دهنده اين است كه مغان بهترين زوج تلاقى با نويد است. از سوى ديخر در بخش نويد محكهاى مغان و روشن قرار داشتند و نويد بهترين زوج تلاقى با اين دو محك بود (شكل ·ل). محكهاى قدس، الوند و بهار در بخش زنوتيبٍ بم قرار داشتند بنابراين بم بهترين زوج تلاقى با اين محكها بود. از آنجا كه محك بم در اين بخش وجود نداشت، كليه تلاقى هاى فوق، هتروتيك بودند. در بخش قدس، محكهاى ارگ و بم وجود داشتند. بنابراين قدس بهترين زوج تلاقى با محكهاى ارگ و بم بود (شكل • (1). اكثر بيش بينى هاى انجام شده را مىتوان از دادههاى موجود در جدول ب تاييد كرد ولى برخى از اين نتايج با دادهها مطابقت نداشتند. اين جنين اختلاف هايى مورد انتظار هستند جرا كه باىيلاتها به ترتيب •7 و ال7 درصد از تغييرات كل را توجيه كردند. از آنجا كه دادهها حاوى خطا هستند و از آنجا كه باىيلات جنين بيشبينىها را بر اساس الكوى كلى دادهها انجام مىدهل، احتمالاً ييشبينى ها نسبت به مشاهدات انفرادى قابليت اطمينان بيشترى دارند ( Yan and Hunt, الني .(2002 در مقايسه با روشهاى متداول تجزيه دىآلل، تجسم

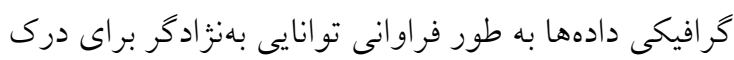

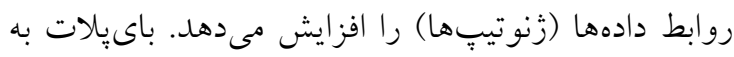
صورت كرافيكى GCA و SCA زنوتيڤٍا، بهترين زوج تلاقى براى هر زنوتيّ، گروههاى هتروتيك و بهترين تلاقى ها را نمايش مى دهد. اين اطلاعات به بهنزادكر براى تمركز بر تعداد كمى از والدين و تلاقىها در مطالعات

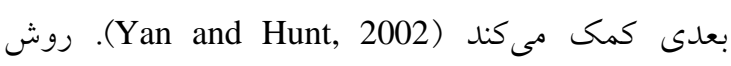
باىيلات سعى در تفسير تنوع فنوتيى تلاقىها توسط شناخت والدين دارد در حالى كه روش متداول تجزيه دىآلل براى توصيف عملكرد فنوتيى تلاقىها طراحى شده است (Yan and Hunt, 2002). رويكرد برد 
معتمدى و صفرى

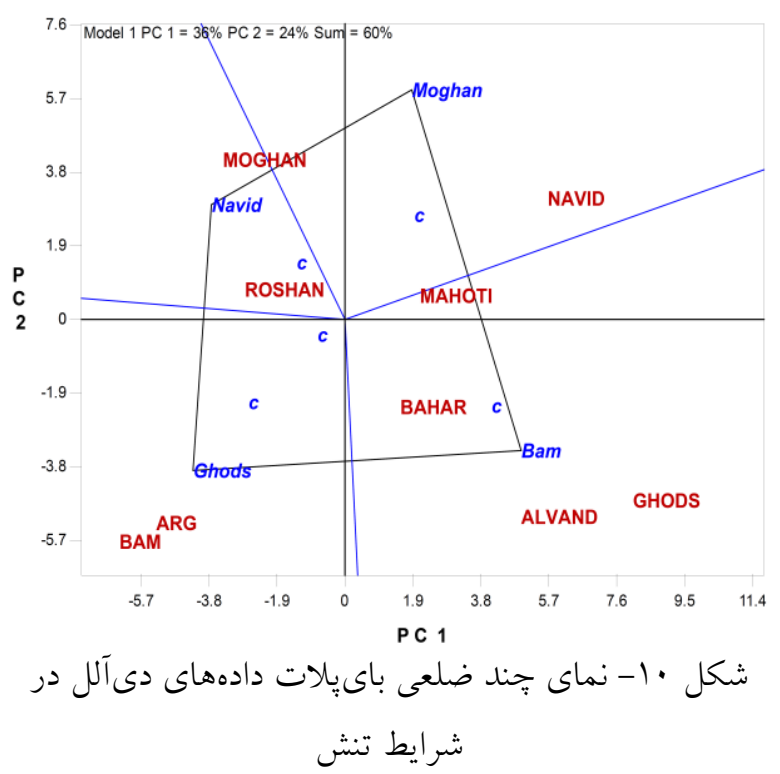

Figure 10. Polygon view for diallel data in stress condition
تجزيه باى يلات دادههاى دى آلل براى تحمل به تنش ...

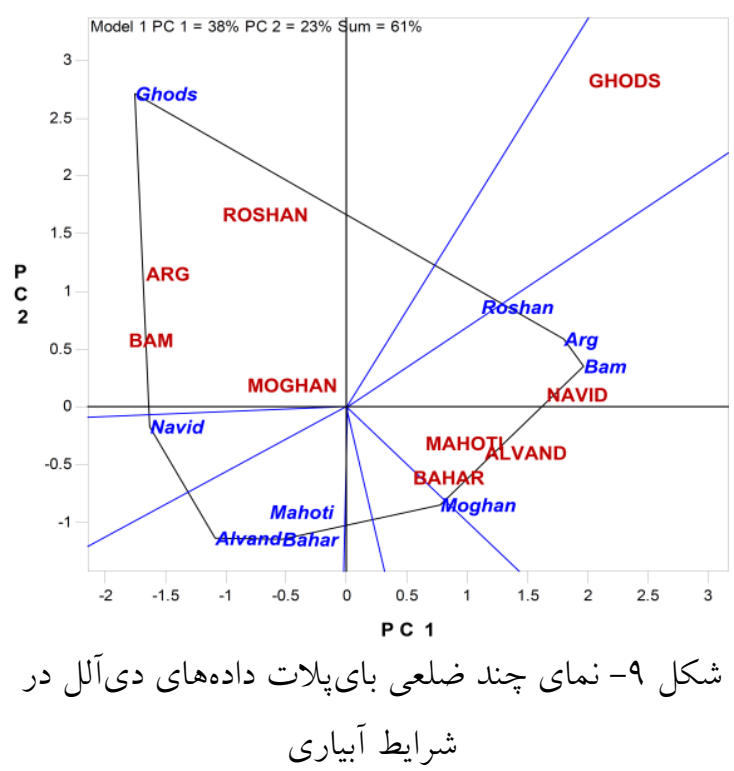

Figure 9. Polygon view for diallel data in normal condition

\section{References}

Borghi, B. and Perenzin, M. (1994). Diallel analysis to predict heterosis and combining ability for grain yield, Yield components and bread making quality in bread wheat (T. aestium). Theoretical and Applied Genetics, 89 (7-8): 815-981.

Farshadfar, E. and Hasheminasab, H. (2012). Investigating the combining ability and genetic constitution of physiological indicators of drought tolerance in bread wheat (Triticum aestivum L.) using GGE biplot methods. International Journal of Plant Breeding, 6(2): 121-128.

Farshadfar, E. and Hasheminasab, H. (2013). Biplot analysis for detection of heterotic crosses and estimation of additive and dominance components of genetic variation for drought tolerance in bread wheat (Triticum aestivum L.). Agriculture Communication, 1(1): 1-7.

Gomez, K.A. and Gomez, A.A. (1984). Statistical procedures for agricultural research. John Wiley \& Sons, New yourk, $680 \mathrm{p}$.

Griffing, B. (1956). Concept of general and specific combining ability in relation to diallel crossing systems. Australian Journal of Biological Sciences, 9(4): 463-493.

Hallauer, A.R., Carena, M.J. and Miranda Filho, J.B. (2010). Quantitative genetics in maize breeding. Springer, New York.

Jinks, J.L. and Jones, M.R. (1958). Estimation of the components of heterosis. Genetics, 43(2): 223234.

Joshi, S.K., Sharma, S.N., Singhania, D.L. and Sain, R.S. (2004). Combining ability in the $F_{1}$ and $F_{2}$ generations of diallel cross in hexaploid wheat (Triticum aestivum L.). Hereditas, 141(2): 115-121.

Kumar, D., Kerkhi, S.A., Singh, G. and Singh, J.B. (2015). Estimates of genetic parameters for grain yield, agro-morphological traits and quality attributes in bread wheat (Triticum aestivum L.). Indian Journal of Agricultural Science, 85(5): 622-627.

Ljubičić, N., Petrović, S., Dimitrijević, M., Hristov, N., Vukosavljev M. and Srećkov, Z. (2014). Diallel analysis for spike length in winter wheat. Turkish Journal of Agricultural and National Sciences, 2: 1455-1459.

Ljubičić, N., Petrović, S., Kostic, M., Dimitrijević, M., Hristov, N., Kondic-spika, A. and Jevtic, R. (2017). Diallel analysis of some important grain yield traits in bread wheat crosses. Turkish Journal of Field Crops, 22(1): 1-7.

Mohammadi, M. and Roustaie, M. (2016). Estimation of Genetic Parameters of Grain Yield and Some Agronomic Traits in Bread Wheat Using Diallel Crosses. Plant Genetic Researches, 2 (2) :57-72 (In Persian).

Mostafavi, K. and Zabet, M. (2013). Genetic study of yield and some agronomic traits in bread wheat using biplot of diallel data. Seed and Plant Improvement Journal, 29(3): 503-518 (In Persian). 
Nezhadahmadi, A., Prodhan, Z.H. and Faruq, G. (2013). Drought tolerance in wheat. The Scientific World Journal, 2013: 1-12.

Raj, P. and Kandalkar, V.S. (2013). Combining ability and heterosis analysis for grain yield and its components in wheat. Jouranl of Wheat Research, 5(1): 45-49.

Sadeghzadeh-Ahari, D., Sharifi, P., Karimizadeh, R. and Mohammadi, M. (2015). Estimation of Genetic Parameters of Morphological Traits in Rainfed Durum Wheat (Triticum turgidum L.) using Diallel Method. Plant Genetic Researches, 2 (1): 45-62 (In Persian).

SAS Institute. (2002). SAS user's guide: Statistics version 9 for windows. SAS Institute, Carry, NC.

Yan, W. (2001). GGEbiplot - a Windows application for graphical analysis of multienvironment trial data and other types of two-way data. Agronomy Journal, 93(5): 1111-1118.

Yan, W. and Hunt, L.A. (2002). Biplot analysis of diallel data. Crop Science, 42(1): 21-30.

Yan, W. and Kang, M.S. (2003). GGE biplot analysis: A graphical tool for geneticists, breeders, and agronomists. CRC Press, Boca Raton, Florida, U.S.A.

Yao, J., Ma, H., Yang, X., Yao, G. and Zhou, M. (2014). Inheritance of grain yield and its correlation with yield components in bread wheat (Triticum aestivum L.). African Journal of Agricultural Research, 13(12): 1379-1385.

Zare-kohan, M. and Heidari, B. (2012). Estimation of genetic parameters for maturity and grain yield in diallel crosses of five wheat cultivars using two different models. Journal of Agricultural Science, 4(8): 74-80.

Zare-kohan, M. and Heidari, B. (2014). Diallel cross study for estimating genetic components underlying wheat grain yield. Journal of Biological and Environmental Sciences, 8(22): 37-51.

Zhang, Y. and Kang, M.S. (1997). DIALLEL-SAS: A SAS program for Griffing's diallel analyses. Agronomy Journal, 89(2): 176-182.

Zobel, B. and Talbert, J. (1984). Applied Forest Tree Improvement. John Wiley \& Sons, New Yourk, U.S.A. 


\title{
Biplot Analysis of Diallel Data for Water Deficit Stress Tolerance in Wheat
}

\section{Mohammad Motamedi ${ }^{1, *}$ and Parviz Safari}

1- Assistant Professor, Department of Agronomy and Plant Breeding, Shoushtar Branch, Islamic Azad University, Shoushtar, Iran

2- Young Researchers Club, Ahvaz Branch, Islamic Azad University, Ahvaz, Iran

(Received: May 30, 2017 - Accepted: October 18, 2017)

\begin{abstract}
Drought stress is one of the most important factors involved in reducing wheat production and identifying genetic structure and gene action type in controlling grain yield in water stress condition is essential for choosing appropriate breeding methods. In this study, 9×9 one way diallel crosses were used to study the genetic structure of wheat grain yield at stress and non- stress conditions. Combining ability analysis by the second Griffing method for both conditions resulted in significant GCA and SCA variances, representing grain yield may be controlled by additive and non- additive effects of genes. The results of applying combining ability analysis indicated that among the parents, genotypes Ghods and Bam had the highest GCA for grain yield and the best specific crosses were Arg $\times$ Ghods, Navid $\times$ Moghan, Bam $\times$ Alvand (for both irrigation regimes) and Bam $\times$ Ghods (in stress condition). Biplot analysis of diallel data was used to display GCA and SCA for parents and to determine heterotic groups and the best crosses. In general, according to the results, Bam, Ghods and Arg were tolerant cultivars and had the ability to maintain yield in drought stress condition as well as to transfer these properties to the hybrids. So these genotypes can be used to improve stress tolerance in breeding programs.
\end{abstract}

Keywords: Diallel, General Combining Ability, Specific Combining Ability, Water deficit stress, Wheat 